\title{
Creating Fictitious Family Memories: The Closed Stranger Adoption of Māori Children into White Families
}

\author{
MARIA HAENGA-COLLINS
}

\begin{abstract}
Between 1955 and 1985 approximately 45,000 closed stranger adoptions took place in Aotearoa New Zealand. Many of these adoptions involved children of Māori ancestry, who were placed into white families, where links to their whakapapa were severed and a space for fictitious narratives (including memories) was created. This article reveals some adoption fictions experienced in the lives of six Māori people who were adopted into Pākehā families. Using a Māori-centred research approach, it found that there were common fictions that Māori adopted people navigated, through counter-narratives and narratives of repair, in their quest to create their own identity.
\end{abstract}

\section{Introduction}

The 1955 Adoption Act effectively ushered in the era of closed stranger adoption in New Zealand. The term "closed stranger adoption" refers to the practice whereby the adoption was closed or secret. Prior to the adoption, the adoptive parents were strangers to the child and remained strangers to the birth parents - there were no social or familial links, and all identifying details of the child's birth parents remained confidential. The child's original birth certificate was "closed" and unable to be accessed, and a new birth certificate showing only the adoptive parents' details was produced. ${ }^{1}$

Such measures were primarily devised as a way of hiding, or legitimising, illegitimate births and provided a way for childless married couples to become parents, fulfilling the expectations of what was socially sanctioned as a "normal family." " The colonial discourse around illegitimacy was one of shame, scandal and dishonour, with the stigma associated with illegitimacy falling upon the birth mother, her family, and her illegitimate child. ${ }^{3}$ For this reason, many birth mothers were put under extreme pressure from their families and from social agencies to have their illegitimate child placed for adoption. ${ }^{4}$ Apart from providing a "normal family" for a child who would otherwise be labelled as illegitimate, closed stranger adoption was viewed as providing a "fresh start" for an unmarried mother who had "fallen from grace." The dominant social script prescribed that a loving birth mother would give her illegitimate child up for adoption and get on with her life. Getting on with her life implied finding a husband and having more children within the confines of marriage. ${ }^{5}$ In this way, the closed stranger adoption of illegitimate children was a socially engineered narrative based on rescuing the child while helping the childless. ${ }^{6}$ A much less benevolent interpretation would understand it in terms of supply and demand in the niche market of babies. ${ }^{7}$

In the two decades following the introduction of the Adoption Act 1955, New Zealand came to have the highest domestic adoption rate in the western world. ${ }^{8}$ In 1970, 7 percent of New Zealand newborns were placed for adoption and in 1998, Keith Griffith, one of New Zealand's foremost researchers on adoption, estimated that adoption directly affected 25 percent of the New Zealand population. ${ }^{9}$ Historian Anne Else describes closed stranger adoption in New Zealand as "a social experiment with unknown and uninvestigated outcomes, conducted on a massive scale." 10 
Although exact numbers were not recorded, it is known that a significant proportion of closed stranger adoptions involved children who could claim Māori ancestry through at least one of their birth parents. The majority of these children were adopted into white families. ${ }^{11}$ Even so, a much smaller number of single Māori mothers, compared with single Pākehā mothers, had a child placed for adoption. That fewer Māori women placed children for adoption is hardly surprising, given that placing a child in an unknown family was culturally inappropriate for Māori. ${ }^{12}$ Closed stranger adoption conflicted with traditional Māori adoption practices in that the adoption took place outside of the whānau and hapū, and the intrinsic secrecy surrounding the adoption separated the adopted child from all knowledge of their whakapapa. Anthropologist, Joan Metge states that, for Māori, placing children secretly with strangers was "severely frowned upon, for it means they are lost to grandparents and whānau as well as birth parents." "13 Nonetheless, aggressive assimilationist policies and the migration of Māori from rural to urban areas in large numbers in the years after World War Two resulted in more Māori children being placed for adoption outside of their whānau as Māori women were more easily able to conceal a pregnancy from extended family. However, the most common reason for the number of Māori children placed for adoption was because this number included children whose mothers were Pākehā and whose fathers were Māori. ${ }^{14}$

According to sociologist Lesley Patterson, more than half of women marrying in the late 1960s were already pregnant at the time of marriage. ${ }^{15}$ For an unmarried woman expecting a child, there were generally only two socially acceptable options available; either marry the father of the child or have the child placed for adoption. However, a Pākehā woman pregnant to a Māori man often faced increased social and familial pressure not to marry a Māori. The option by default therefore was to place the child for adoption.

Historian Anne Else records instances where Māori family members actively pursued the right to adopt related children who were being placed for adoption by Pākehā birth mothers. ${ }^{16}$ Yet adoption law and practices "which did not recognise Māori concepts of family and kinship"17 meant adoption by Pākehā strangers was viewed as more desirable than adoption by Māori kin. Applications made by grandparents to legally adopt their grandchildren were turned down on the basis that they were too elderly and did not meet certain financial standards. Former Chief Judge Eddie Taihakurei Durie elaborates: "Social workers put a lot of blocks on grandparents adopting grandchildren . . . it [was] not written into statute at all, just a working policy adopted by social workers ... not too many [Māori] met the [income] test."18 Māori grandparents wanting to legally adopt a child were denied the right to do so as they were deemed to be "too old and too poor." 19 Further, underlying racism and disdain for anything Māori meant that courts viewed a European upbringing as superior to that which a child would receive in a Māori home. This was despite the fact that Māori babies were considered "hard to place," as fewer white parents wanted a brown child. Ironically, this resulted in Māori children being disproportionately placed into Pākehā homes that social workers knew were less than satisfactory. ${ }^{20}$

\section{Methodology and Research Design}

Much of the research about closed stranger adoption in Aotearoa New Zealand focuses on the general population of adopted people and their birth mothers. To date there remains little specific research relating to Māori adoptees who were cross-culturally adopted into Pākehā families under closed stranger adoption. ${ }^{21}$ Globally, cross-culturally adopted people have had limited opportunities to articulate their own adoption experiences. The experiences of cross- 
cultural adoptees have largely been transmitted by white adoptive parents and privileged white professionals. In their book Outsiders Within: Writing on Transracial Adoption, cross-cultural adoptees Trenka, Oparah, and Shin explain, "Over the past fifty years, white adoptive parents, academics, psychiatrists and social workers have dominated the literature on transracial adoption. These "experts" have been the ones to tell the public - including adoptees - "what it's like' and 'how we turn out' ... the voices of adult transracial adoptees remain largely unheard ... [we] fear that expressing our opinions will estrange us from our white families, friends and colleagues." 22

This article, drawn directly from the author's master's thesis, addresses this critique as it is based upon semi-structured in-depth interviews undertaken with six adults who identify as Māori and were adopted into Pākehā families as children. ${ }^{23}$ Further, the author is herself a cross-cultural adoptee. The research design recognised the importance of remaining open and responsive to the experiences and concerns that the participants themselves wanted to address. As such, the participants were encouraged to talk not only about their adoption, but about their lives in general. Audio recordings of interviews with the participants were produced and later transcribed. Common themes were identified, and a narrative analysis of those themes was undertaken.

The use of narrative was important for at least three reasons. First, people create meaning through narratives, and live their lives according to the stories they tell about themselves and the stories that others tell about them. ${ }^{24}$ Stories are central to our sense of identity, and these stories produce meanings in particular social, cultural, and historical contexts. As sociologist Avril Bell states, "We don't just construct our sense of identity out of thin air, but out of the ways of thinking and relating that we inherit from the past." ${ }^{25}$ Hence, "stories are necessary to weave a web of meaning within which we can live. We all live in story worlds. They create for us the atmosphere of understandability that seems necessary for ordinary survival." ${ }^{26}$ Second, narratives provide a way to encompass great diversity. ${ }^{27}$ Narratives are therefore a useful tool in examining the contradictions and tensions present in the stories told by Māori adopted into Pākehā families. Sociologist Catherine Riessman states that as a narrative approach "gives prominence to human agency and imagination, it is well suited to studies of subjectivity and identity." 28 The question of identity as both Māori and an adopted person is central to this study, with the participants creating counter-narratives, or narratives of repair, to assist in making meaning of their experiences. Third, given that the literature surrounding adoption (particularly cross-cultural adoptions) often refers to cultural disconnection, a narrative approach offers a way of identifying, analysing, and creating "a meaningful pattern on what would otherwise be random and disconnected." 29 This fits with a Māori-centred research approach which aims to "tie all aspects of Māori experiences back together in a purposeful manner" 30 and is consistent with Māori oral traditions.

As the original research was designed to provide a space for the voices of adopted people, it is important to briefly introduce each participant so that their narratives are not disconnected from what they want to share with us. The six participants who shared their narratives are:

- Ana. Born in 1960, Ana was adopted into a middle-class Pākehā family that already had three non-adopted children. As an adult, Ana reconnected with both her Māori birth parents.

- Carole. Born in the early 1960s, Carole was adopted into a Pākehā family where both her adoptive parents were alcoholic. She had two older adoptive siblings who would 
tease her because she was brown. As an adult, Carole met her birth mother who was Pākehā, but her birth father remains unknown to her.

- Cordelia. Born in the 1960s, Cordelia was physically abused in the strictly religious Pākehā family she was adopted into. As an adult, Cordelia met a sibling related through their birth mother and the two of them have been in a long-term committed relationship. This has resulted in both professional and personal hardships.

- Elizabeth. Born in the early 1970s, Elizabeth grew up in a loving and stable Christian family; however, her adoptive parents were never told that Elizabeth's birth father was Māori and neither they nor Elizabeth found this out until she connected with her birth mother as an adult.

- Kaare. Born in the 1960s, the term takatāpui encapsulates both Kaare's sexual and Māori identities. He has two younger siblings born to his adoptive parents. Kaare met his Pākehā birth mother as an adult; however, no information was provided about his birth father.

- Marion. Born in the 1950s, Marion was adopted into a middle-class Pākehā family that had four much older children. Marion did not try and find her birth parents out of respect for her adoptive parents until they had both passed away. She was a married woman with two children when she first met her Cook Island mother and relations of her Māori birth father who had died some years before.

While this study has its limitations, in that only six people were interviewed, the rich, in-depth narratives provide intimate details of the adoption fictions that the participants had to navigate. This navigation oftentimes resulted in the creation of counter-narratives as a response to the secrets, silences, and shame experienced in cross-cultural closed adoptions, and as such provide insight into often unexplored internal processes.

\section{Themes from the Narratives}

The complexities and contradictions in the participants' narratives reflect the complexities and contradictions Māori who were adopted into Pākehā families have navigated throughout their lives as Māori, and as adopted people. The narratives collected cluster around notions of secrets, silences, and shame-which can be traced back to the often-fictitious stories the participants were told by family, friends and society. Psychotherapist Ann Nation, who has personal connections to adoption, highlights that the stories adopted people were told were "open to the different perspectives and beliefs of the adopted parents and the vagaries of society's views at the time." 31 While some stories were based on fact, other stories were manufactured in the belief that what was being told was beneficial to the child. Moreover, adopted people were often unable to ask questions about what they were told, or what they themselves imagined or assumed, for fear of breaking the silence surrounding adoption and upsetting their adoptive parents. It was a widely held belief that if an adopted person asked questions about their birth identity they were either emotionally and mentally unwell, ungrateful, or both. ${ }^{32}$

\section{The Fiction of "as if Born to"}

The role closed stranger adoption played in normalising Anglo-Christian ideals about families is reflected in the 1955 Adoption Act, which provided for:

- The automatic conferral of a new name on the adopted child;

- The consent to an adoption with the birth mother having no knowledge of who, or where, her child was going to; 
- The birth parents not attending the adoption hearing; and

- The adopted child ceasing to be the child of the birth parents and having all the legal rights of a child of the adoptive parents, "as if born to them in lawful wedlock." 33

Closed adoptions based on these provisions provided fertile ground for inaccuracies and fictions. The "as if born to" clause perpetuated the assumption that adopted children would fit seamlessly into their adoptive families and that it was best, for everyone involved, to pretend the adoption had never happened, or at least play down the fact that it had. ${ }^{34}$ The issuing of a new birth certificate containing only the adoptive parents' details and the subsequent closure of files containing any information about the birth parents were "legal fictions" which aided in the pretences and secrets of closed stranger adoption.

It was not until 1985, with the enactment of the Adult Adoption Information Act 1985, that it was possible for adopted people, twenty years of age and over, to gain access to their original birth certificate and to the names of their birth parents, if no veto had been put in place. The importance of naming or renaming oneself is a way Māori adopted into Pākehā families have been able to assert their identity and resist the fiction created through the new, or false, birth certificate. After meeting her birth family, it was important for Ana to change from the name she was given when she was adopted to a name which reflected both her family of origin and her adoptive family. Ana describes her motivation at the time as, "I'm going to change my name. .. . I'm gonna go and be who I need to be." 35 This was particularly difficult for Ana as her decision wasn't welcomed or accepted by everyone in her adoptive family. However, Ana's determination clearly illustrates the importance of names and naming which was evident in all the participants' narratives as they sought to find a way to express their Māori and adoption identities. Narratives around names and naming make it possible for Māori adopted into Pākehā families to compose a narrative repair over the loss of their original birth identity and the feeling of not fully belonging in their adoptive families. Some of the participants chose pseudonyms for this study from names that were given to them at birth or which in some way connected them with their birth mother.

Confronting a loss of identity and acknowledging a lack of "'belonging" is painful, but allows a counter-narrative which expresses the realities of loss associated with adoption to be articulated and explored. Cordelia provides an example of a participant directly acknowledging that she did not belong to the adoptive family when she says, "I'm not going to try anymore to belong to you [adoptive family]. I'm going to accept that actually, I don't." Cordelia goes on to explain how disconnected she felt in her adoptive family, stating, "I had no one and I don't think people know when they're not adopted what it's like to have no one, to literally feel like you have no one who has your back." 36

Such disconnection can be narrated as rejection. A "rejection" narrative mirrors the wider societal narrative during the period of closed stranger adoptions which presented unmarried mothers as having "unwanted babies." "37

\section{The Fiction of "Unwanted Babies"}

To support the view that childless married couples were morally entitled to adopt, the notion that babies born to unmarried mothers were "unwanted babies" was yet another socially constructed fiction. As late as the 1970s, articles were being published which advanced the "unwanted baby" narrative. Many social workers working with unmarried mothers loathed the use of the term "unwanted" for illegitimate children as they knew this was untrue, yet the term 
remained in popular use as a euphemism for "illegitimate." 38 Adopted people came to believe that they had been "unwanted" and "given away" by mothers who had never loved them. Paradoxically, although most birth mothers felt they had little choice but to place their child for adoption, they also took on society's views, feeling responsible and guilty for having "given away" their babies.

The "unwanted baby" narrative also enabled adoptive parents to look past their often-painful reasons for wanting to adopt. Rather than focussing on infertility or the pain of miscarrying a pregnancy, they were able to focus instead on helping a needy child. If children were "unwanted," they did not "belong" to anybody. Their mothers had "given them away." Newborns could come to their new family without a past as there had been a clean break from their birth mother. Societal conventions imagined that the birth mother's scandalous slate had been wiped clean while the child's slate remained suitably blank.

The "unwanted baby narrative" became an internalised rejection narrative for many adopted people, as it was common for adopted people to believe that they were abandoned by their birth mothers. Language such as being "given away" and "unwanted" was used in all but one of the narratives collected. This became the psychological truth for this group of people.

Kaare clearly articulates feelings of rejection and how this plays out: "just that core thing of rejection and not belonging, and not feeling adequate enough, and not feeling like I could be a positive in the equation. I always felt like I was a negative, a subtraction as such, or something that was distracting from the actual flow." ${ }^{39}$ Carole further explains, "I can still feel rejected in a second, I can still feel like I don't belong. There's all those core things inside of me."40 Additionally, Ana talks about "being given away": "Adoption really does do your head in babe, that whole being given away and abandonment and there is a real level about that." 41

This sense of rejection can also be traced back to the "chosen narrative" where adopted people "personalise their placement for adoption as rejection. To be chosen they must first be rejected." 42 The chosen narrative was yet another socially constructed narrative creating the notion of the bad (rejecting) birth mother and the good (choosing) adoptive mother/family. Even when this comparison was not directly made by anyone, the adopted person was likely to internalise this social script.

Interestingly, Else notes that adoptive parents wanting to do the right thing by their adopted child were advised by social workers to tell the child that they were special or chosen. ${ }^{43}$ The "how you came to belong to us" stories remain vivid in the memories of participants. Three participants specifically talked about how they were "chosen." Cordelia said, "My adopted family had told me that my mum couldn't look after me and that's the reason why they had me and I was loved and I was special." "44 Marion remembers her adoptive father telling her she was chosen-“"That was his words, I was 'chosen'; no mention of the word adoption. So my picture that I built up was these rows of babies somewhere, I'm assuming a hospital, and so he just went along and picked that baby." 45 Kaare too believed as a child that he was picked from a row of babies- "I was told that I was picked up off the special counter. . . . I had to go to the supermarket for babies and I was on the special counter so they got me.... And that's it, how they chose me. And my mum and my dad chose me over all the other children that were there. $" 46$ 
These narratives reflect the ways in which families who adopted children built their own truths for the children they adopted. One way that Māori adopted into Pākehā families have navigated the "chosen" narrative was through the counter-narrative of "rebellion." It was a way an adopted person could assert their own identity and test how "special" they were, and perhaps how wanted. According to Ann Nation, some form of rebellion is common for most adolescents, but for adopted people this need to rebel is to be expected as "a normal consequence of an un-normal situation." ${ }^{47}$ Kaare confirms this when he states, "At one stage, yeah when I was, I don't know how old, a bit of a kick back stage of, 'Oh yeah special; I'll show you how special I am! Hmm!’ And away I went. Self-destruct." 48

Cordelia illustrates how difficult it is for Māori adopted into Pākehā families, especially when there is little or no guidance available to either the child or the adoptive family, when she says, "So I was special! Felt like special needs! And I stuck out a mile all the time, and I had a strange name! The Māori didn't know what to make of me; thought I was a Pākehā. And I always felt too Māori to be Pākehā, and too Pākehā to be Māori, so what does that mean? No one told me that was actually okay." 49 The rebellion response to the "chosen" narrative also gives the adopted person a voice. In contrast to being "given" an adoption story, rebellion is a way to assert one's own story. It draws attention to the "secret" and the "silence" associated with being adopted. Consequently, it is a way adopted people can position themselves, even if only temporarily, outside of their adoptive family. Ana says, "When I got into my teenage years it [adoption] helped me even be more rebellious. . . . you go through those formative years. I think they must have been very difficult for all children but I wore my adoption sometimes like a badge, as a, 'Oh you think you've had a bad time . . . you know, this is me!'"50

Rebellion made adoption tangible and allowed the adopted person to create their own identity as opposed to the identity that had been imposed through the adoption process. Marion shared what this was like for her: "Suddenly I didn't get on with my [adoptive] mother . . . whenever we had a row or something, it was always, 'Oh well, you didn't want to adopt me anyway,' and the adoption thing often came out in arguments. 'Well, I'm gonna go and find my family' type stuff. It was always sitting there." 51

\section{The Fiction of "the Same as"}

A foundational principle within closed stranger adoption was matching children as closely as possible to their adoptive families. For example, matching of hair, eye and skin colouring, perceived intellectual abilities (taken from the birth parent's educational or social standing) and religious beliefs. ${ }^{52}$ Matching adoptive parents and child as closely as possible was viewed as an important factor in creating a positive placement. Such matching, which especially focused on physical similarities, was also viewed as aiding in the secrecy of the adoption. For Māori adopted into Pākehā families, this matching becomes problematic and fed into the hierarchy of babies, where children who looked more European were easier to place than children who were darker in complexion. ${ }^{53}$

As Else reports, "Though they saw all mixed race children as difficult to place, the degree of 'darkness' counted too, because some Pakeha couples said they would accept children who were light enough or whose non-European ancestry did not 'show." ${ }^{54}$ Written reports by social workers during the 1950s reveal how significant the child's appearance was: "The baby is rather sweet and quite fair, and has no characteristics at all of the Maori race." ${ }^{55}$ However, racial origins were often viewed as more important than skin colouring, with many potential 
adoptive parents still not willing to consider a child with the possibility of any Māori parentage, no matter how light skinned.

Some Pākehā adoptive parents, aware that their adopted child had Māori ancestry, would themselves hide this fact. Ann Nation recalled how "people talked about the [Māori] child as being of Greek descent or Spanish descent ... people told sort of fibs, about what the truth was, because they didn't want people to know."56 Some social workers hid the fact that the child had a Māori father as they were often desperate to find a home for an otherwise "hard to place" child, and Pākehā birth mothers realised hiding that the father was Māori increased the probability that their child would "go to a good" family. ${ }^{57}$

This fiction of a non-Māori ethnicity was usually only uncovered after the passing of the Adult Adoption Information Act 1985, when many adopted people were able to make contact with birth parents. Elizabeth talks about her adoptive family, and the added grief experienced when she found out as an adult her father was Māori: "I wasn't told that I was Māori . . . I just can't believe that no one thought that was important enough to tell me. I feel like I missed out for 20 years ... you miss all those things that just happen in life ... I missed that. I missed that with [my birth mother] . . . I missed it with [my birth father] and I missed it being Māori."

For Māori people adopted into Pākehā families who were more visibly identifiable as Māori the fiction of "the same as" the adoptive parents, and sometimes adoptive siblings, was never possible. For Māori adoptees, a physical dissimilarity with their adoptive Pākehā family could elicit curious comments and racist reactions. The lack of physical resemblance within the adopted family contributed to a narrative of disconnection for all the participants. Kaare recalls that his adoptive father "used to jump in and stop people from being too racist," which would often happen with strangers who didn't realise he was with his family. ${ }^{59}$

Other participants revealed the racism within their adoptive families. Carole shared, "We used to have a little book called The Little Black Sambo, and my brother, my older brother wrote on the top of it 'nigger' and said it was me, and put my name there. . . and those are my first memories of being different." 60

Elizabeth acknowledged 'that there weren't too many highs or too many lows [within the adoptive family]. It was really stable and caring, and you know I had lots of opportunities. . . . Like, I guess my adoption, it's really sweet." But she also knew that she was different: "They didn't look like me . . . I always knew I was adopted . . . so I always knew I was different from them." 61 Marion shares a similar experience: "I didn't look like anybody else. I was darker than everybody else [in my adoptive family]." 62

Such comments emphasise how Māori adopted into Pākehā families were forced to acknowledge looking different from their adoptive families, which led them to view themselves as different. Thus, another significant divide was created and notions that they were "as if born to" and "the same as" their adoptive family remained unachievable.

\section{Conclusion}

The secrets, silencing, and shame surrounding closed stranger adoption provided fertile ground for the creation of specific fictions which included the legal falsification of an adopted person's original birth certificate and in some cases the production of inaccurate details about an adopted persons ethnicity and family of origin. Adopted people in this research navigated the fictions 
of "as if born to," "unwanted babies," and "the same as," through complex and sometimes contradictory counter-narratives and narratives of repair. These counter-narratives provided a way for the participants to make sense of their experiences, and to position themselves as both Māori and as adopted people.

Regardless of the quality of their adoption experience, a deep sense of rejection and loss were common themes in the narratives shared by the participants in this study. This remained a catalyst for participants wanting to seek a connection with their birth families, while any reconnection would also potentially connect participants with their Māori cultural heritage. Breaking out of the pretence of adoption was a way for Māori adults who had been adopted as children into Pākehā families to navigate the narratives of not belonging and a loss of cultural connection.

\footnotetext{
${ }^{1}$ Sheryn Gillard-Glass and Jan England, Adoption New Zealand: The Never-Ending Story (Auckland: HarperCollins, 2002), 25.

${ }^{2}$ Anne Else, A Question of Adoption (Wellington: Bridget Williams Books, 1991), 25; Ani Mikaere, The Balance Destroyed (Wellington: Te Wānanga o Raukawa, 2017), 106.

${ }^{3}$ Gillard-Glass and England, Adoption New Zealand, 19, 35.

${ }^{4}$ Else, A Question of Adoption, 39-47; Josh Shawyer, Death by Adoption (Auckland: Cicada Press, 1979), 10-13; Maria Haenga-Collins, "Closed Stranger Adoption, Māori and Race Relations in Aotearoa New Zealand,

1955-1985" (PhD thesis, Australian National University, 2017), 109-20, https://openresearchrepository.anu.edu.au/handle/1885/132619

${ }^{5}$ Else, A Question of Adoption, 41.

${ }^{6}$ Anne Else, “"The Need is Ever Present': The Motherhood of Man Movement and Stranger Adoption in New Zealand," The New Zealand Journal of History 23 (1989): 48, http://www.nzjh.auckland.ac.nz/docs/1989/NZJH_23_1_06.pdf

${ }^{7}$ Else, "The Need is Ever Present," 48; See also Marian Quartly, Shurlee Swain, and Denise Cuthbert, The Market in Babies: Stories of Australian Adoption (Victoria, Australia: Monash University Publishing, 2013).

${ }^{8}$ Mary Iwanek, "Adoption in New Zealand-Past, Present and Future," in Adoption and Healing:

Proceedings of the International Conference on Adoption and Healing (Wellington: New Zealand Adoption and Healing Trust, 1997): 62-73.

${ }^{9}$ Keith Griffith, New Zealand Adoption: History and Practice, Social and Legal, 1840-1996

(Wellington: K. C. Griffith, 1998), 21-25; The Adoption New Zealand website states that "more than two million New Zealanders have a direct link to adoption." Adoption New Zealand, accessed 18 November 2019, http://adoptionnz.com/

${ }^{10}$ Else, A Question of Adoption, 197.

${ }^{11}$ Maria Haenga-Collins, "Belonging and Whakapapa: The Closed Stranger Adoption of Māori

Children into Pākehā Families" (MA thesis, Massey University, 2011), 8,

https://mro.massey.ac.nz/handle/10179/3195

${ }^{12}$ Hirini Moko Mead, Landmarks, Bridges and Visions: Aspects of Maori Culture (Wellington: Victoria University Press. 1997), 204-11.

${ }^{13}$ Joan Metge, New Growth from Old: The Whānau in the Modern World (Wellington: Victoria University Press, 1995), 213.

${ }^{14}$ Haenga-Collins, "Belonging and Whakapapa," 23.

${ }^{15}$ Lesley Patterson, "Parenting-Marriage, Separation and Sole Parenting," Te Ara-The Encyclopedia of New Zealand, http://www.TeAra.govt.nz/en/parenting/3

${ }^{16}$ Else, A Question of Adoption, 182, 188-190.
} 
${ }^{17}$ Maria Haenga-Collins and Anita Gibbs, "'Walking between Worlds': The Experiences of New Zealand Māori Cross-Cultural Adoptees," Adoption \& Fostering 39, no. 1 (2015): 62-75.

${ }^{18}$ Haenga-Collins, "Belonging and Whakapapa," 23.

${ }^{19}$ Haenga-Collins, "Belonging and Whakapapa," 23.

${ }^{20}$ Else, A Question of Adoption, 79-80.

${ }^{21}$ Research by Māori adopted people to date includes: Haenga-Collins, "Belonging and Whakapapa"; Haenga-Collins, "Closed Stranger Adoption"; Erica Newman, "A Right to be Māori? Identity Formation of Māori Adoptees" (MA thesis, University of Otago, 2012), https://ourarchive.otago.ac.nz/handle/10523/2219; Emma West, "Manu is my Homegirl: Navigating the Ethnic Identity of the Māori Adoptee" (MA thesis, University of Waikato, 2012), https://openrepository.aut.ac.nz/handle/10292/4614

22 Jane Jeong Trenka, Julia Chinyere Oparah, and Sun Yung Shin, Outsiders Within: Writing on Transracial Adoption, (Cambridge, MA: South End Press, 2006), 1.

${ }^{23}$ Haenga-Collins, "Belonging and Whakapapa."

${ }^{24}$ Miller Mair, Between Psychology and Psychotherapy: A Poetics of Experience (London: Routledge, 1989), 277.

${ }^{25}$ Avril Bell, Relating Indigenous and Settler Identities: Beyond Domination (Hampshire: Palgrave Macmillan, 2014), 122.

${ }^{26}$ Mair, Between Psychology and Psychotherapy, 277.

${ }^{27}$ Paul Spickard and Jeffrey Burroughs, "We Are a People," in We Are a People: Narrative and Multiplicity in Constructing Ethnic Identity, ed. Paul Spickard and Jeffrey Burroughs (Philadelphia: Temple University Press, 2000), 1-20.

${ }^{28}$ Catherine Kohler Riessman, Narrative Analysis, Qualitative Research Methods Series 30 (Newbury Park: Sage Publications, 1993), 5.

${ }^{29}$ Catherine Kohler Riessman, Narrative Methods for the Human Sciences (Los Angeles: Sage Publications, 2008), 5.

${ }^{30}$ Leland Ruwhiu, "Te Pūawaitanga o te Ihi me te Wehi: The Politics of Māori Social Policy Development" (PhD thesis, Massey University, 1999), 37.

${ }^{31}$ Haenga-Collins, "Belonging and Whakapapa," 53.

${ }^{32}$ Else, A Question of Adoption, 145; Haenga-Collins, "Closed Stranger Adoption," 74.

${ }^{33}$ Adapted from: Gillard-Glass and England, Adoption New Zealand, 25.

${ }^{34}$ Else, A Question of Adoption, 51-52.

${ }^{35}$ Haenga-Collins, Belonging and Whakapapa, 61.

${ }^{36}$ Haenga-Collins and Gibbs, "Walking Between Worlds," 69.

${ }^{37}$ Else, A Question of Adoption, 51-52, 156.

${ }^{38}$ Haenga-Collins, "Closed Stranger Adoption," 52.

${ }^{39}$ Haenga-Collins, "Belonging and Whakapapa," 62.

${ }^{40}$ Haenga-Collins and Gibbs, "Walking Between Worlds," 69.

${ }^{41}$ Haenga-Collins and Gibbs, "Walking Between Worlds," 69.

${ }^{42}$ Deborah N. Silverstein and Sharon Kaplan, "Seven Core Issues in Adoption," available at http://vanish.org.au/media/17324/seven-core-issues-in-adoption.pdf

${ }^{43}$ Else, A Question of Adoption, 144-47.

${ }^{44}$ Haenga-Collins, "Belonging and Whakapapa," 53

${ }^{45}$ Haenga-Collins, "Belonging and Whakapapa," 53.

${ }^{46}$ Haenga-Collins, "Belonging and Whakapapa," 53.

${ }^{47}$ Haenga-Collins, "Belonging and Whakapapa," 53.

${ }^{48}$ Haenga-Collins, "Belonging and Whakapapa," 54.

${ }^{49}$ Haenga-Collins, "Belonging and Whakapapa," 54.

${ }^{50}$ Haenga-Collins, "Belonging and Whakapapa," 54.

${ }^{51}$ Haenga-Collins, "Belonging and Whakapapa," 54.

${ }^{52}$ Else, A Question of Adoption, 76-77. 
${ }^{53}$ Else, A Question of Adoption, 73-75. See also Aaron Smale, "New Zealand's Problem with Māori Boys," in The Spinoff, March 27 2018, https://thespinoff.co.nz/atea/27-03-2018/new-zealandsproblem-with-maori-boys/

${ }^{54}$ Else, A Question of Adoption, 74.

${ }_{55}^{55}$ Else, A Question of Adoption, 74.

${ }^{56}$ Haenga-Collins, "Belonging and Whakapapa," 24.

${ }^{57}$ Else, A Question of Adoption, 74.

${ }^{58}$ Haenga-Collins, "Belonging and Whakapapa," 56.

${ }^{59}$ Haenga-Collins, "Belonging and Whakapapa," 49.

${ }^{60}$ Haenga-Collins and Gibbs, "Walking Between Worlds," 70.

${ }^{61}$ Haenga-Collins, "Belonging and Whakapapa," 56; Haenga-Collins and Gibbs, "Walking Between Worlds," 68.

${ }^{62}$ Haenga-Collins and Gibbs, "Walking Between Worlds," 70. 